\title{
Pervious Concrete as an Alternative for Non-structural Drainage to the Amazon Region: From Properties to Applications in Watersheds
}

\author{
Lourenço Bechara $^{1,2}$, Juliano Ponte ${ }^{2}$ and Márcio Barata ${ }^{2}$ \\ 1. Instituto Federal do Pará Campus CDA, Conceição do Araguaia 68540-000, Brasil \\ 2. Programa de Pós-Graduação em Arquitetura e Urbanismo, Universidade Federal do Pará, Belém, 66075-110, Brasil
}

\begin{abstract}
The urbanization process of the urban centers in the Amazon occurred quickly and without planning. Belém, one of the main cities in the region, suffers from intense flooding due to urbanization growth and the disorderly occupation of floodplains. The objective was to evaluate the producing of pervious concrete that meets the mechanical and hydraulic performance criteria for permeable pavement molded on site and to simulate the replacement of the entire public walkway system of a hydrographic basin in Belém in order to verify if this measure would alter the permeability of the basin and meet minimum requirements of at least $25 \%$ permeable area. The properties of three mixtures of pervious concrete with aggregates of different grading were evaluated. The permeability and flexural strength of all blends were higher than the minimum required for use as a permeable pavement for light vehicle traffic. The simulation showed that replacement of the public walkway by permeable pavement increased the permeable area of the watershed from 19 to $23 \%$, changing from a poor condition to an acceptable level. The results indicate the potential to improve the performance of drainage systems through the wider use of permeable pavement associated with traditional structural measures.
\end{abstract}

Key words: Pervious concrete, permeable pavement, non-structural drainage, floods, high rainfall, Amazon region.

\section{Introduction}

The growth of the urban population and the consequent unplanned occupation of territories results in soil waterproofing, a process that considerably increases the runoff velocity and eliminates the natural percolation of the waters. When this occurs in the marginal areas to watercourses and floodplains, flood points are generated both by excessive rainfall and by high tides [1].

The classic solution of urban drainage system implementation is based on the rapid transfer of effluents to the downstream. The primary collection is made by the channeling of rainwater from plots and public areas, called micro drainage, to a channel system with a large volume of transport and retention, called macro-drainage. However, the evaluation of

Corresponding author: Lourenço Bechara, professor, research fields: architecture and urbanism. this system shows some problematic operating issues, such as the increase in the flow velocity that generates the transport and accumulation of solid waste at the points of collection and storage, causing frequent flooding and the creation of specific flooding areas [2-5].

Due to failure of the classic drainage system in the 1970s in Western Europe and part of North America (United States and Canada), non-structural or comprehensive drainage technologies emerged. They are called so because they compensate the effects of urbanization through the control of excess water due to waterproofing, which avoids fast transfer downstream. They control the volumes of water at the source with a decrease and delay of flood spikes [1, 6].

The city of Belém, the object of this study, located in the Brazilian Amazon, Pará State Capital, is an example of the application of this practice of a 
traditional drainage system and its failures. Located at the confluence of rivers in the estuary and delta zone of the Amazon River and its tributaries, on the north coast of Brazil, the city receives an annual rainfall of over 3,000 $\mathrm{mm}$, which causes the flooding of rivers and fluvial plains (Table 1). In terms of maximum rainfall in 24 hours, the values ranged from 59 to 136 $\mathrm{mm}$, with an average time of return of 30 years [7].

The first records of large floods in Belém occurred in the 1970 s caused by the urban expansion of the city [8]. The causes of these phenomena are mainly due to urbanization and disordered occupation of the floodplains. However, in the particular case of Belém, the floods are aggravated because the city is intersected by a dense water network and has flat relief, which is associated with the high rainfall indices and to the fact that it is influenced by the river regime of the estuary zone leading to the formation of a dam that damages the water drainage system [5].

In February 2018, the rainfall index in Belém reached $80.8 \mathrm{~mm}$. This volume of rain corresponds to almost six times the expected volume for a whole day in this rainy season. To aggravate the situation, the tide in Belém reached a maximum volume of 2.9 meters. Shortly before the peak time, the floodgates of the canals were closed automatically, so that the tidal water did not advance over the city and overflow to the canals. However, with rain well above average in a short time, the canals did not support the large volume of water and overflowed in the lowest points of the city [9] (Fig. 1).

The adoption of non-structural approaches in conjunction with structural systems would be the most appropriate for Belém. One possibility would be the use

Table 1 Some average and extreme meteorological data from Belém: Period 1962 to 1996 [7].

\begin{tabular}{llllll}
\hline \multirow{2}{*}{ Month } & \multicolumn{2}{c}{ Air temperature $\left({ }^{\circ} \mathrm{C}\right)$} & \multicolumn{2}{c}{ Rainfall $(\mathrm{mm})$} \\
\cline { 2 - 6 } & Max. & Min. & Average & Total & Max. $(24 \mathrm{~h})$ \\
\hline Jan & 31.1 & 22.9 & 26.0 & 378.1 & 107 \\
Feb & 30.7 & 23.0 & 25.8 & 426.6 & 130 \\
Mar & 30.7 & 23.1 & 26.0 & 441.3 & 136 \\
Apr & 31.2 & 23.3 & 26.2 & 381.5 & 125 \\
May & 31.8 & 22.9 & 26.4 & 299.8 & 105 \\
Jun & 32.0 & 22.5 & 26.2 & 172.0 & 95 \\
Jul & 32.0 & 22.6 & 26.5 & 160.7 & 101 \\
Aug & 32.4 & 22.6 & 26.6 & 140.0 & 88 \\
Sep & 32.6 & 22.7 & 26.8 & 139.8 & 54 \\
Oct & 32.7 & 22.9 & 27.0 & 119.3 & 73 \\
Nov & 32.2 & 23.0 & 26.7 & 122.7 & 59 \\
Dec & 31.8 & 22.9 & 26.4 & 210.6 & 109 \\
Year & 31.8 & 22.9 & 36.6 & $3,000.3$ & 136 \\
\hline
\end{tabular}

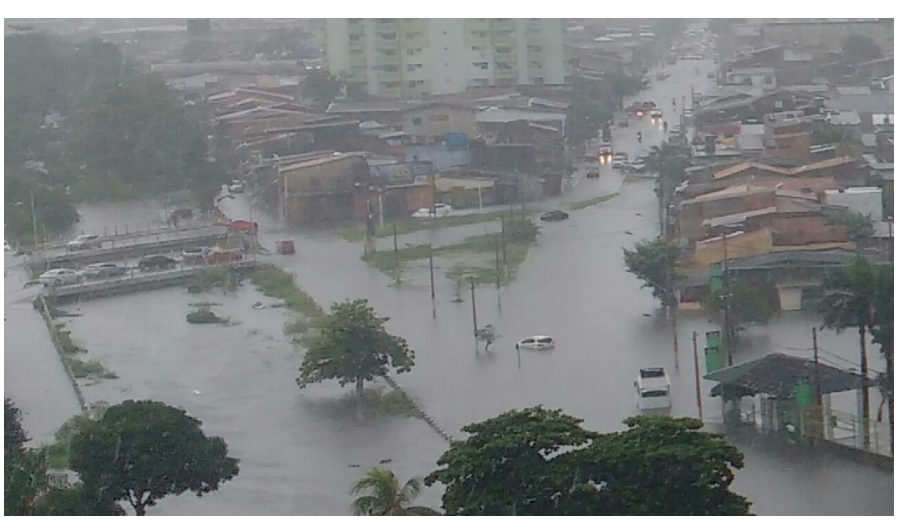

Fig. 1 Flooding in Belém in February 2018 [9]. 
of porous pavements that would allow increased permeability of surfaces or temporary storage of water such as parking areas, public walkways and secondary road systems. In both cases, there would be a reduction of the surface runoff, with a slow and gradual release of the water to the traditional drainage system or allowing its infiltration into the soil. In the latter case, the use of porous pavements with partial or total infiltration may not be viable for Belém, especially during the rainy season, because the very high rainfall saturates the soil, raising the level of the water table. One possibility would be the use of porous retention pavements with direct injection, that is, with storage capacity designed for specific rainfall events, which are dictated by local requirements. In this case, temporary storage of rainwater would be carried out with the damping of the flow rates and the runoff velocity, allowing the hydrographs to be changed. The infiltration rate of soil would not be considered in this situation.

The drainage projects of the metropolitan region of Belém (MRB) do not contemplate comprehensive or non-structural conceptions. There are no practical examples of the use of permeable pavement in the city and scientific studies of the implantation of these systems are scarce. Preliminary research investigated the production of pervious concrete with gravel of quartz, a coarse aggregate available in the most cities located in the Amazonian plain [10]. It is a weak sedimentary rock called conglomerate whose Los Angeles abrasion values range from 55 to $70 \%$,

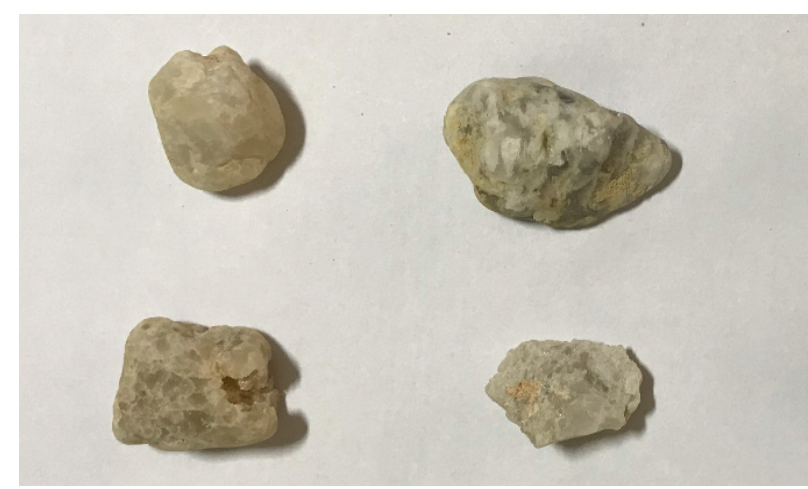

demonstrating its fragility under cyclic vehicle loading conditions [11]. The results were not satisfactory in terms of mechanical properties and permeability, not reaching the limits established by the Brazilian standard [10].

This paper aimed to evaluate if pervious concretes produced with crushed rock from granite, an igneous rock of less availability than the gravel in the MRB, would reach the properties required for use in permeable pavements. Fig. 2 illustrates gravel and the crushed rock, both available for productions of concrete in MRB. The first one is with greater supply availability and lower acquisition cost.

The second part of the paper carried out a simulation using a simplified calculation, replacing the entire public sidewalk of a MBR watershed for permeable pavement. The objective was to verify if this measure would change the permeability of the basin in order to meet the minimum requirements of at least $25 \%$.

The simulation has an illustrative character and an estimative principle, substantiating the investigation of the pervious concrete mixtures and allowing the visualization of order of magnitude and the identification of potential gains from the incorporation of permeable concrete pavements and its application in a real context. The basin chosen was Una, the largest watershed in the municipality of Belém in terms of territorial area and population. The Una Basin recently underwent construction of a macro drainage project, which extended from the 1980s to the

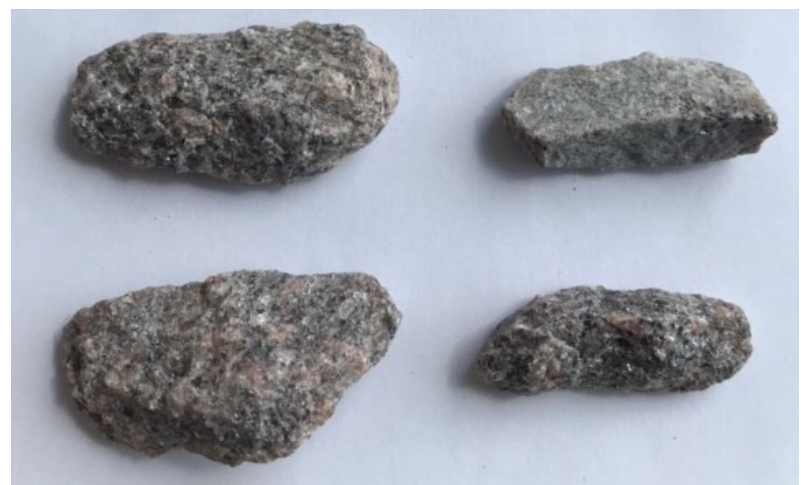

Fig. 2 Coarse aggregates available at MRB: gravel (left) and crushed granite rock (right). 
2000s. Despite this, the Una Basin presents recurring flooding problems in its territory, which not only stems from the lack of maintenance but also from the relationship between morphology, land occupation and urban infrastructure devices. Cases such as the Una Basin are not exceptional and reflect the need to think of non-structural measures as a concept of urban drainage.

\section{Experimental Program}

\subsection{Materials}

The Portland cement used was CP II Z 32 with 14\% pozzolan and 5\% limestone in accordance with Brazilian standard ABNT NBR 16697. The coarse aggregate was granite with a density of $2.84 \mathrm{~kg} / \mathrm{m}^{3}$, absorption of $0.46 \%$ and Los Angeles abrasion value less than $20 \%$. The shape of the particles was classified as elongated according to the Brazilian standard ABNT NBR 6954 (Fig. 2), since the ratio $b / a$ was less than 0.5 and $c / b$ was greater than 0.5 ( $a$ : length, $b$ : width, $c$ : thickness). In the experimental program three graduations of coarse aggregate were used: U1 (19-12.5 mm), U2 (12.5-6.3 $\mathrm{mm})$ and U3 (6.3-2.36 mm), consequently, three mixtures of pervious concrete were evaluated, and their characteristics are presented in Table 2.

\subsection{Specimen Preparation}

The mix proportion of the pervious concretes followed the methodology proposed by Castro et al. [12], in which a fixed volume of $25 \%$ of cement paste was established for all graduations of coarse aggregates, regardless of the void index of each of them. Three small slabs of concrete with dimensions of $150 \times 410 \times 710 \mathrm{~mm}$ were molded, one for each concrete mix, by filling steel molds in two layers of equal volume. The compacting process was carried out by passing a metal roller $(100 \mathrm{~mm}$ diameter, 390 $\mathrm{mm}$ long and $25 \mathrm{~kg}) 15$ times per layer, corresponding to a linear mass of $65 \mathrm{~kg} / \mathrm{m}$ [12]. After molding, the slabs were covering with a geotextile membrane to hold the moisture. This procedure persisted until the 28th day after molding. Fig. 3 illustrates the surface texture aspect of a pervious concrete mixture after molding as well as its cohesive characteristics.

The specimens obtained from the concrete slabs consisted of cutting and extraction procedures. For each slab, the concrete was cut to obtain three prismatic specimens with dimensions of $100 \times 100 \times$ $400 \mathrm{~mm}$ for the flexural strength test and three cubes of $100 \mathrm{~mm}$ of edge for determination of the apparent density and the total void ratio. In addition, three cylinders of $100 \mathrm{~mm}$ in diameter and $150 \mathrm{~mm}$ in length were extracted for the permeability test.

The apparent density of the hardened concrete followed the procedures of Brazilian standard ABNT NBR 9778. The total void ratio was calculated by dividing the difference between the mass of the oven-dried cube $(W 2)$ and the mass of the cube submerged in water $(W 1)$, both in $\mathrm{kg} / \mathrm{m}^{3}$, by the volume of the sample $(V)$ in $\mathrm{m}^{3}$, multiplied by the density of water $(\rho w)$ in $\mathrm{kg} / \mathrm{m}^{3}$ [13]. The Eq. (1) shows the calculation of the total void ratio $(V r)$.

$$
V r=\left(1-\frac{W 2-W 1}{\rho w \cdot V}\right)
$$

Table 2 Proportions of the pervious concrete mixtures.

\begin{tabular}{|c|c|c|c|c|c|c|}
\hline \multirow{2}{*}{ Mixture } & \multirow{2}{*}{$\begin{array}{l}\text { Aggregate particle size range } \\
(\mathrm{mm})\end{array}$} & \multirow{2}{*}{$\begin{array}{l}\mathrm{W} / \mathrm{C} \\
\text { ratio }\end{array}$} & \multirow{2}{*}{$\begin{array}{l}\mathrm{C} / \mathrm{CA} \\
\text { ratio }\end{array}$} & \multicolumn{3}{|c|}{$\begin{array}{l}\text { Mixture proportions } \\
\left(\mathrm{kg} / \mathrm{m}^{3}\right)\end{array}$} \\
\hline & & & & $\mathrm{W}$ & $\mathrm{C}$ & $\mathrm{CA}$ \\
\hline$\overline{\mathrm{U} 1}$ & $19-12.5$ & & $1: 3.92$ & & & 1,402 \\
\hline U2 & $12.5-6.3$ & 0.38 & $1: 3.77$ & 136 & 357 & 1,349 \\
\hline U3 & $6.3-2.36$ & & $1: 3.72$ & & & 1,330 \\
\hline
\end{tabular}

W: water, C: cement, CA: coarse aggregate. 

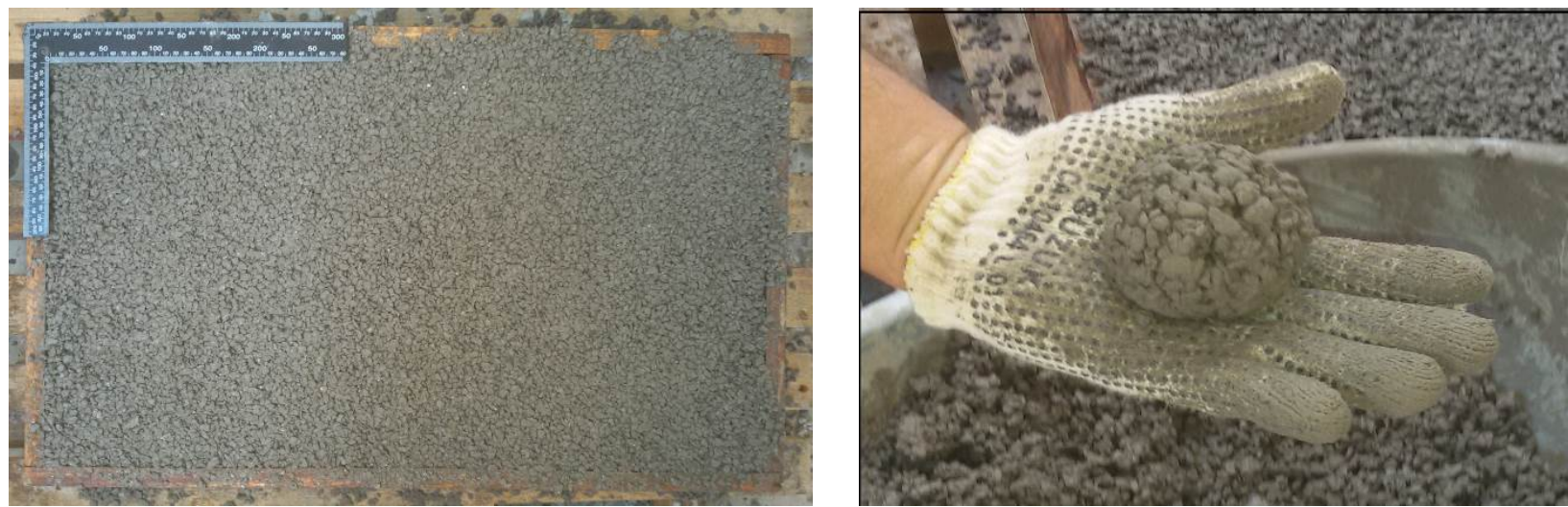

Fig. 3 Surface texture and cohesive characteristics of $U 3$ pervious concrete mix.

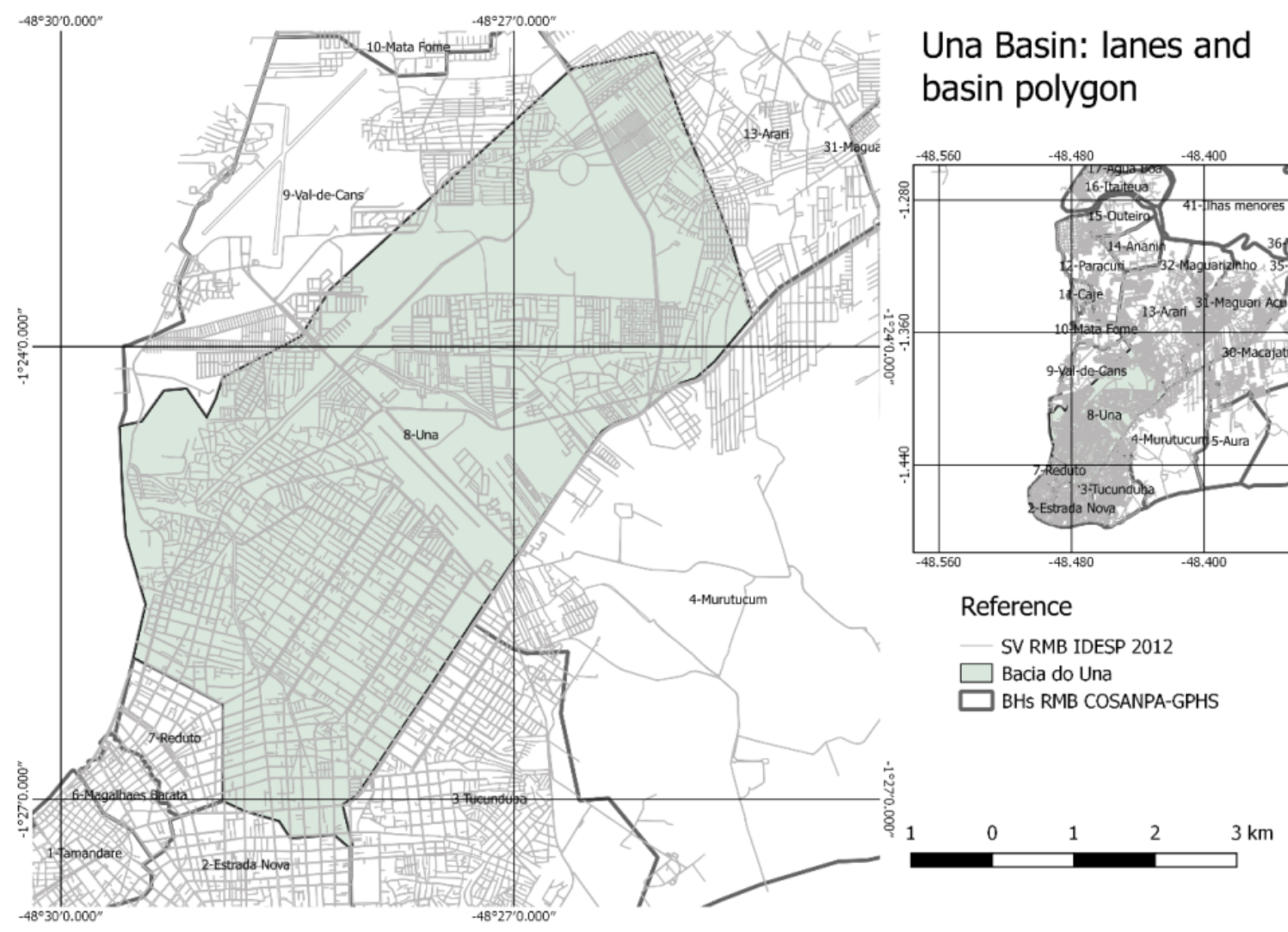

Fig. 4 The Una Basin road system and territorial delimitation $[14,15]$.

The determination of the permeability coefficient in pervious concretes followed the methodology proposed by Neithalath et al. [13], adopted by ACI 522-R10 to obtain the permeability in the laboratory. The flexural strength of the prismatic specimens was determined according to the Brazilian standard ABNT NBR 12142. The results of all investigated properties were obtained from the means of three specimens.

\subsection{Simulation of the Permeable Area of the Watershed}

The urban micro watershed of the Una Basin, located around the water course of the same name, extends in the northeast direction of the territory of the municipality of Belém, as shown in Fig. 4 and was used as the basis for the simulation. The Una Basin 
has a territorial area of 3,607 ha and a demographic density corresponding to 154 habitants per hectare (hab/ha). The basin has an average soil permeability of $18.66 \%$ and a site slope of $1.80 \%$. These parameters are, respectively, lower than the technically desirable minima for both situations, which would be permeability of approximately $25 \%$ (according to Schueler's diagram) and terrain slopes between 2.5 and 5\% [16]. The total length of its road system is $466 \mathrm{~km}$, representing a capillarity of 0.13 $\mathrm{km}$ of road per urbanized hectare $(\mathrm{km} / \mathrm{ha})$, which is considered an average-low parameter for the Belém settlement patterns [17].

We considered the minimum roadway width established by law in the Municipality of Belém [18], which is 9 meters wide, consisting of two lanes 3.00 $\mathrm{m}$ wide and two sidewalks $1.50 \mathrm{~m}$ wide. Of the total 9 meters, $3.00 \mathrm{~m}$ are related to the sidewalk usually paved with conventional, non-permeable concrete.

The simulation calculation procedure of the hypothetical situation of enlargement of the permeable area of the Una Basin consisted in adding to the already existing $18.66 \%$, the contribution of the pavement area of the public walkway of the river basin system, considering the substitution of the current material, with impermeable characteristics, by the permeable pavement consisting of pervious concrete surface and compacted stone subbase of which the thicknesses considered were 100 and 150 mm, respectively..

The storage capacity of the pavement layers is their effective porosity, that portion of the layers that can be filled with rain in service. The effective porosity of pervious concrete was $15 \%$. In the case of the subbase, considering compacted clean stone, the porosity adopted was $40 \%$.

\section{Results and Discussions}

\subsection{Apparent Density}

The apparent density results of the pervious concretes are shown in Table 3. The dispersion of the results was reduced with a standard deviation ranging from $4.1 \mathrm{~kg} / \mathrm{m}^{3}$ to $16.75 \mathrm{~kg} / \mathrm{m}^{3}$, lower than the recommended limit value of $\pm 80 \mathrm{~kg} / \mathrm{m}^{3}$ by the Brazilian standards ABNT NBR 16416, ACI 522R-10 and by Tennis et al. [19].

The apparent density of the mixtures ranged from 2,102 to $2,264 \mathrm{~kg} / \mathrm{m}^{3}$, which is considered high for pervious concretes since the vast majority of the research found in the literature has pervious concrete densities lower than $2,000 \mathrm{~kg} / \mathrm{m}^{3}$ [20-26].

The high apparent density values are attributed to the compaction energy employed and the dosage characteristics of the pervious concretes, more specifically to the relative proportion of each material in the mixture. The coarse aggregate/cement ratio ranged from 3.7 to 3.90 with cement consumption of $357 \mathrm{~kg} / \mathrm{m}^{3}$ and a water/cement ratio of 0.38 for all the mixtures investigated. The low ratio of coarse aggregate to cement $(<4.0)$ contributed to the apparent density increase since there is a substantial percentage of Portland cement in the mixture, and this material has a higher density than the crushed rock. In addition, the granite used has a high density of approximately $2,800 \mathrm{~kg} / \mathrm{m}^{3}$. Similar results were found in the literature, obtaining apparent density higher than $2,000 \mathrm{~kg} / \mathrm{m}^{3}$ for coarse aggregate/cement ratios below 4 [12, 23].

The compaction procedure used by passing the roller 15 times per layer also contributed to the high apparent density of these pervious concretes. This confirms the importance of the compacting energy on

Table 3 Apparent density of the hardened concrete.

\begin{tabular}{lll}
\hline Mixture & Granulometric range $(\mathrm{mm})$ & Apparent density $\left(\mathrm{kg} / \mathrm{m}^{3}\right)$ \\
\hline U1 & $19-12.5$ & $2,264 \pm 5.56$ \\
U2 & $12.5-6.3$ & $2,216 \pm 16.75$ \\
U3 & $6.3-2.36$ & $2,102 \pm 4.11$ \\
\hline
\end{tabular}




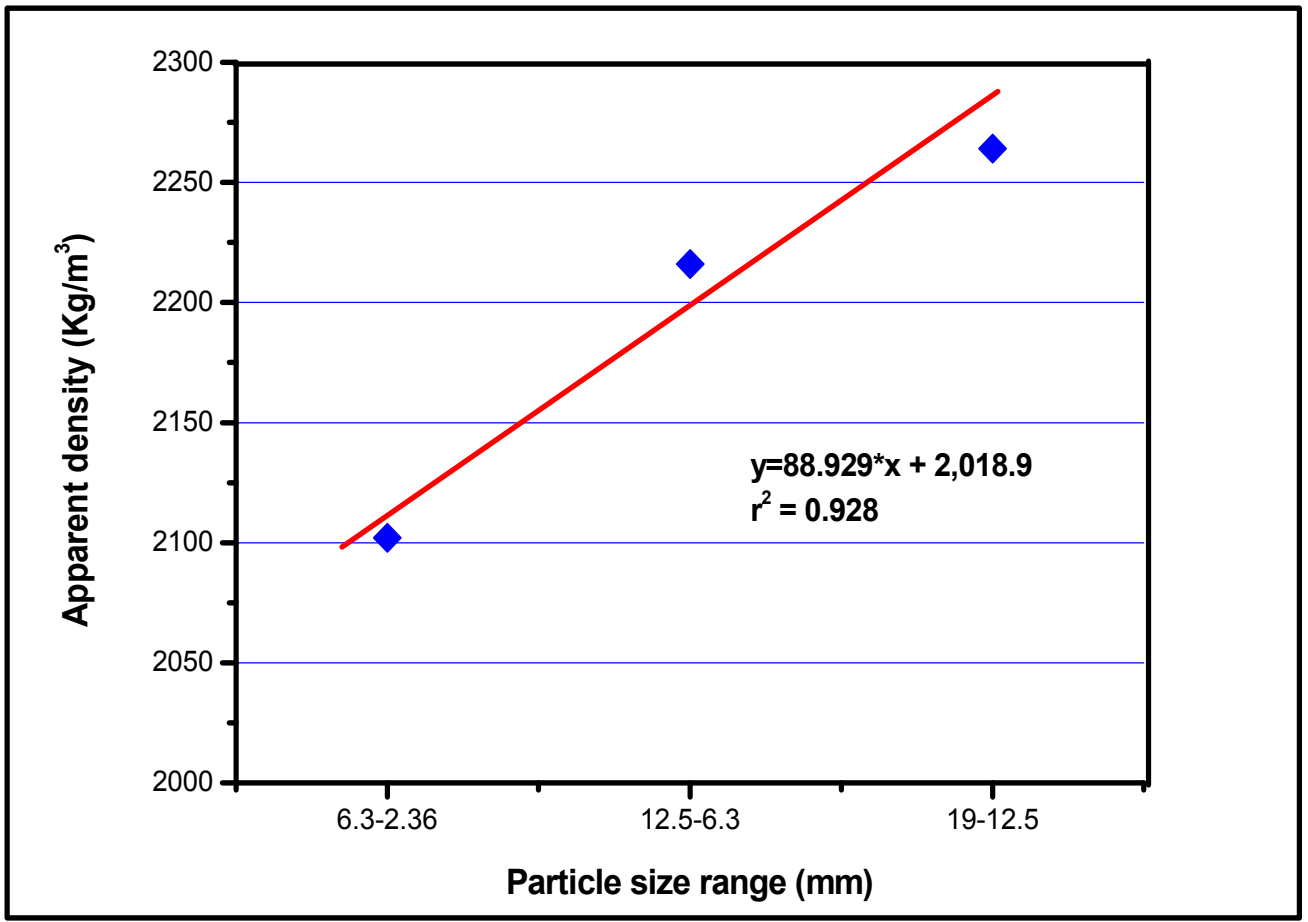

Fig. 5 Relation between apparent density and particle size range.

the mechanical properties and the permeability of pervious concretes [21-23, 27].

Fig. 5 clearly illustrates the well-defined trend of increasing the apparent density of pervious concretes to particles larger sized coarse aggregate. The linear regression model adopted explains $93 \%$ of the total variability, which validates the correlation. In theory, smaller coarse aggregates would provide more contact points between the particles due to a larger specific surface area, which would lead to a lower percentage of voids and, consequently, the apparent density of the pervious concrete mixtures would be larger. In this case, it is evident that other characteristics of the crushed rock, unlike the dimension, exerted a significant influence on this behavior. According to Neville [28], the shape of the particles also interferes with the void index of the aggregates.

The crushed granitic rock used in the production of pervious concretes has elongated particles in all granulometric fractions, both in the larger and smaller ones (Fig. 2). This prevents a more isotropic accommodation of the aggregates in the investigated pervious concrete mixtures. The lamellar particles tend to settle in a preferential plane that hinders the contact between grains, increasing the porosity. There is no tendency to reduce porosity as the aggregate size is reduced because the arrangement formed by the preferential planes of the lamellar particles overlaps.

Another aspect that may have contributed to this behavior is related to the dosage method, in which a fixed volume of paste for all the concrete mixes was established, regardless of the different indices of the aggregate voids. Torres, Hu and Ramos [29] show the higher the paste volume, the greater the coating of the aggregate and, consequently, the lower the porosity and permeability. As the cement paste volume was set at $25 \%$ for all concretes, in the case of mixtures with larger aggregates, that is, with smaller specific surface area, the lower the coverage area, the greater the thickness of the cement paste surrounding the particles, causing a reduction in porosity and a subsequent apparent density increase. 


\subsection{Total Void Index}

The results of the total void index of the pervious concretes are shown in Table 4. The dispersion of the results found was reduced with a standard deviation ranging from 0.36 to $0.71 \%$, and a coefficient of variation in the range of 1.52 to $3.58 \%$.

The total void index of the pervious concretes varied between 19 and 24\%, an acceptable range considering that the porosity normally found in the literature varies between 15 and 30\%. Fig. 6 shows that there was not a well-defined correlation between the total void ratio and particle size. The reduced coefficient of determination of the linear regression $\left(r^{2}\right)$ predicts only $30 \%$ of the variations in the void index explained by the particle size. This behavior is attributed to the two aspects previously discussed regarding the apparent density.

The presence of elongated particles in the crushed rock made it difficult to achieve greater grain entanglement, increasing the porosity mainly for mixtures with smaller aggregates. The establishment of a fixed volume of cement paste resulted in a lower porosity for the mixtures of concrete with a larger aggregate due to the greater thickness of the paste. These superimposed effects increased the porosity of the mixtures with smaller aggregates and reduced it

Table 4 Void ratio of hardened concrete.

\begin{tabular}{lll}
\hline Mixture & Granulometric range $(\mathrm{mm})$ & Void ratio $(\%)$ \\
\hline U1 & $19-12.5$ & $21.55 \pm 0.45(2.08 \%)$ \\
U2 & $12.5-6.3$ & $19.08 \pm 0.71(3.58 \%)$ \\
U3 & $6.3-2.36$ & $23.61 \pm 0.36(1.52 \%)$ \\
\hline
\end{tabular}

Coefficients of variation: values between parentheses.

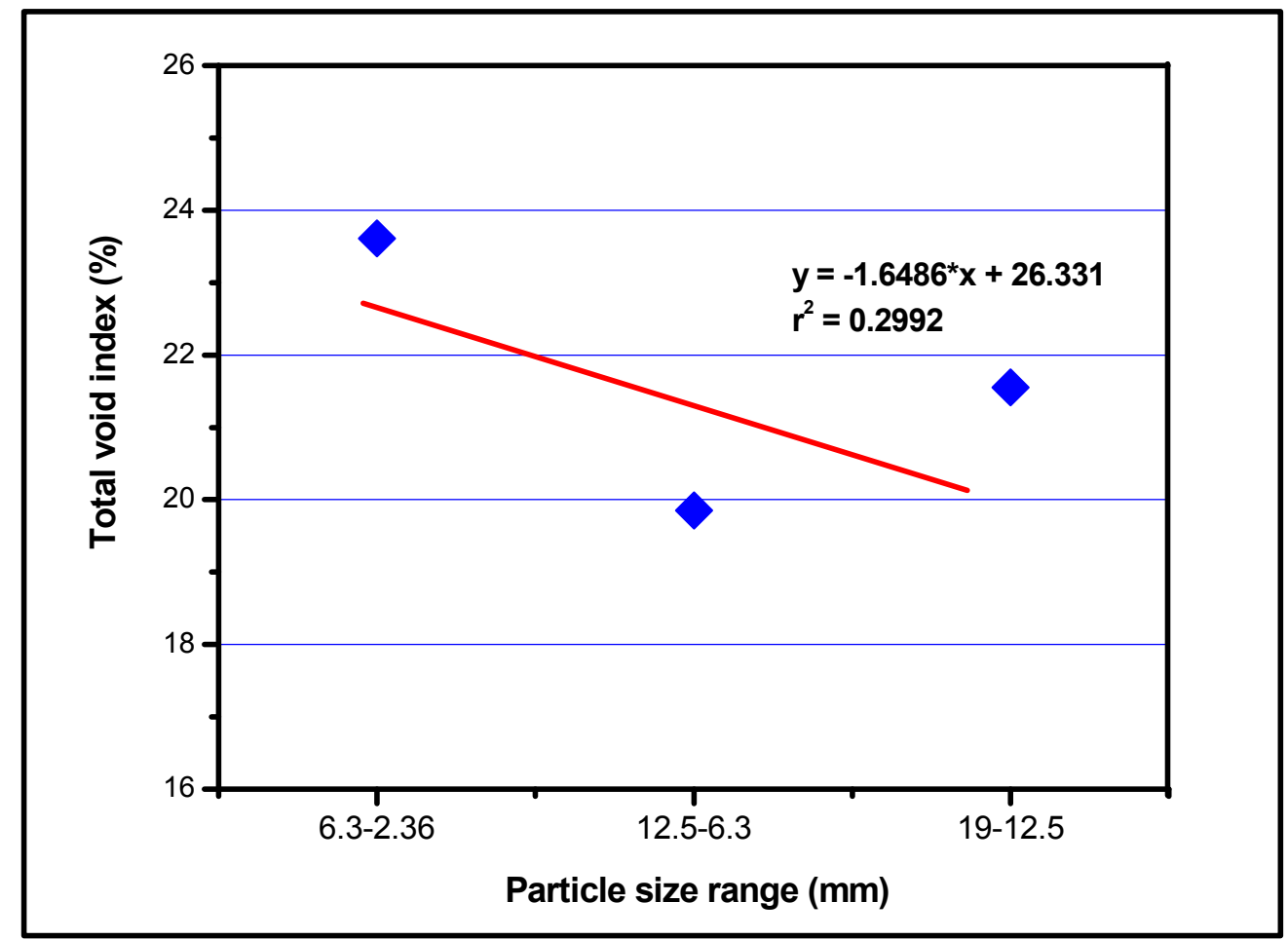

Fig. 6 Relation between total void index and particle size range. 
for the concretes with larger aggregate particles. This explains the absence of a well-defined correlation between the total void ratio and particle size.

Regarding the apparent density of the pervious concrete, Fig. 7 shows that the correlation between the total void index and the apparent density is not very representative, with a correlation coefficient $\left(r^{2}\right)$ of $42 \%$. It is believed that this correlation was not more statistically significant because of the effects already mentioned. However, it is possible to see a trend of reduction of the total voids index with the increase of the particle size, behavior similar to that observed with the apparent density. The higher the density, the lower the total voids.

\subsection{Permeability Coefficient}

The results of the permeability coefficient $(k)$ of the pervious concretes are shown in Table 5. The dispersion of the results found was small with a standard deviation ranging from 0.04 to $0.27 \mathrm{~mm} / \mathrm{s}$ and coefficients of variation in the range of 1.12 to $5.43 \%$

Fig. 8 shows that the permeability coefficients of pervious concrete varied from $2.15 \mathrm{~mm} / \mathrm{s}$ to 3.87 $\mathrm{mm} / \mathrm{s}$, well above the minimum limits stipulated by Brazilian standard ABNT NBR 16416 and ACI 522R-10.

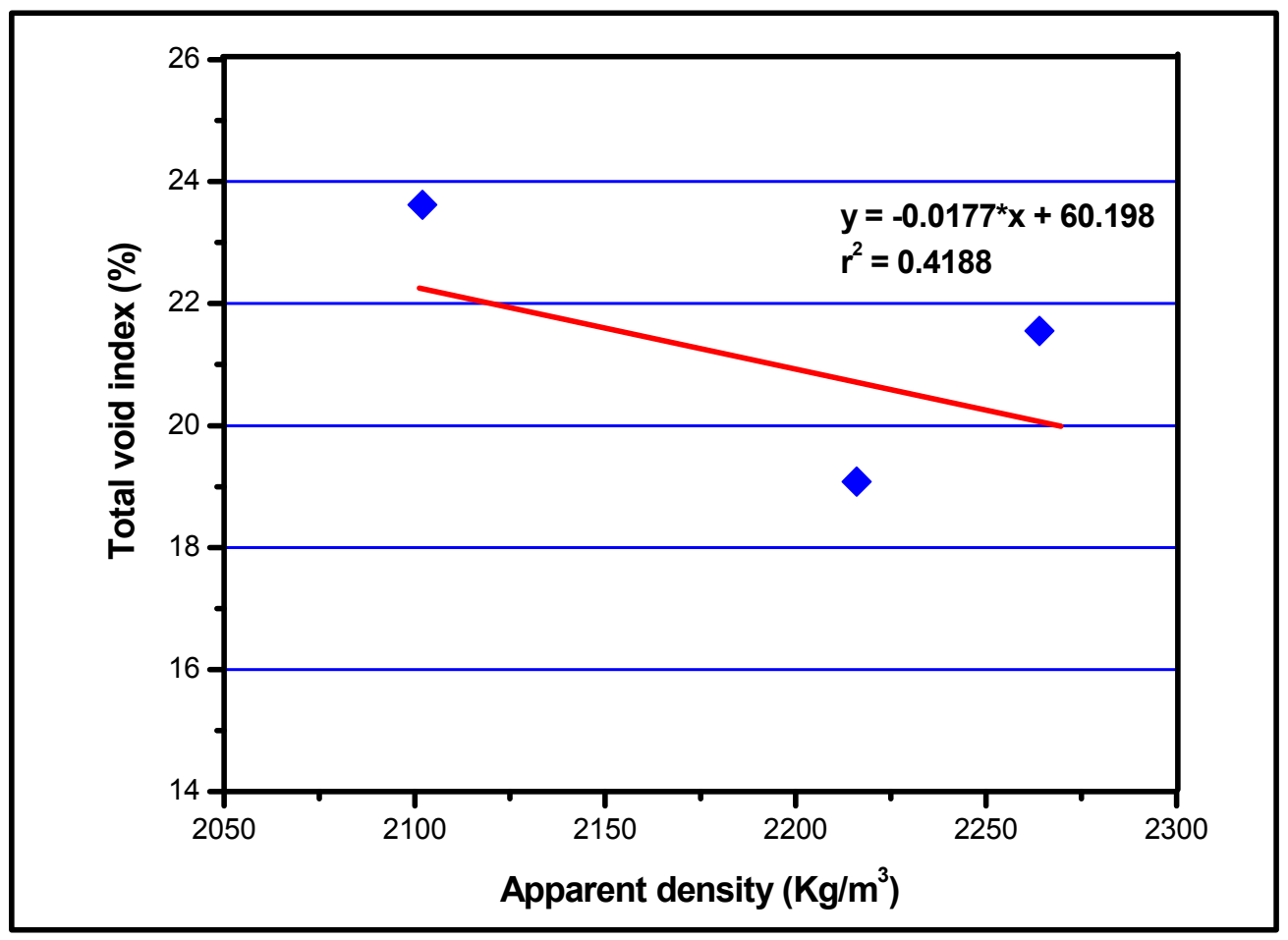

Fig. 7 Relation between total void index and apparent density.

Table 5 Permeability coefficient of hardened concrete.

\begin{tabular}{lll}
\hline Mixture & Granulometric range $(\mathrm{mm})$ & Permeability Coef. $(\mathrm{mm} / \mathrm{s})$ \\
\hline U1 & $19-12.5$ & $3.87 \pm 0.0435(1.12 \%)$ \\
U2 & $12.5-6.3$ & $2.38 \pm 0.11(4.84 \%)$ \\
U3 & $6.3-2.36$ & $2.15 \pm 0.27(5.43 \%)$ \\
\hline
\end{tabular}

Coefficients of variation: values between parentheses. 


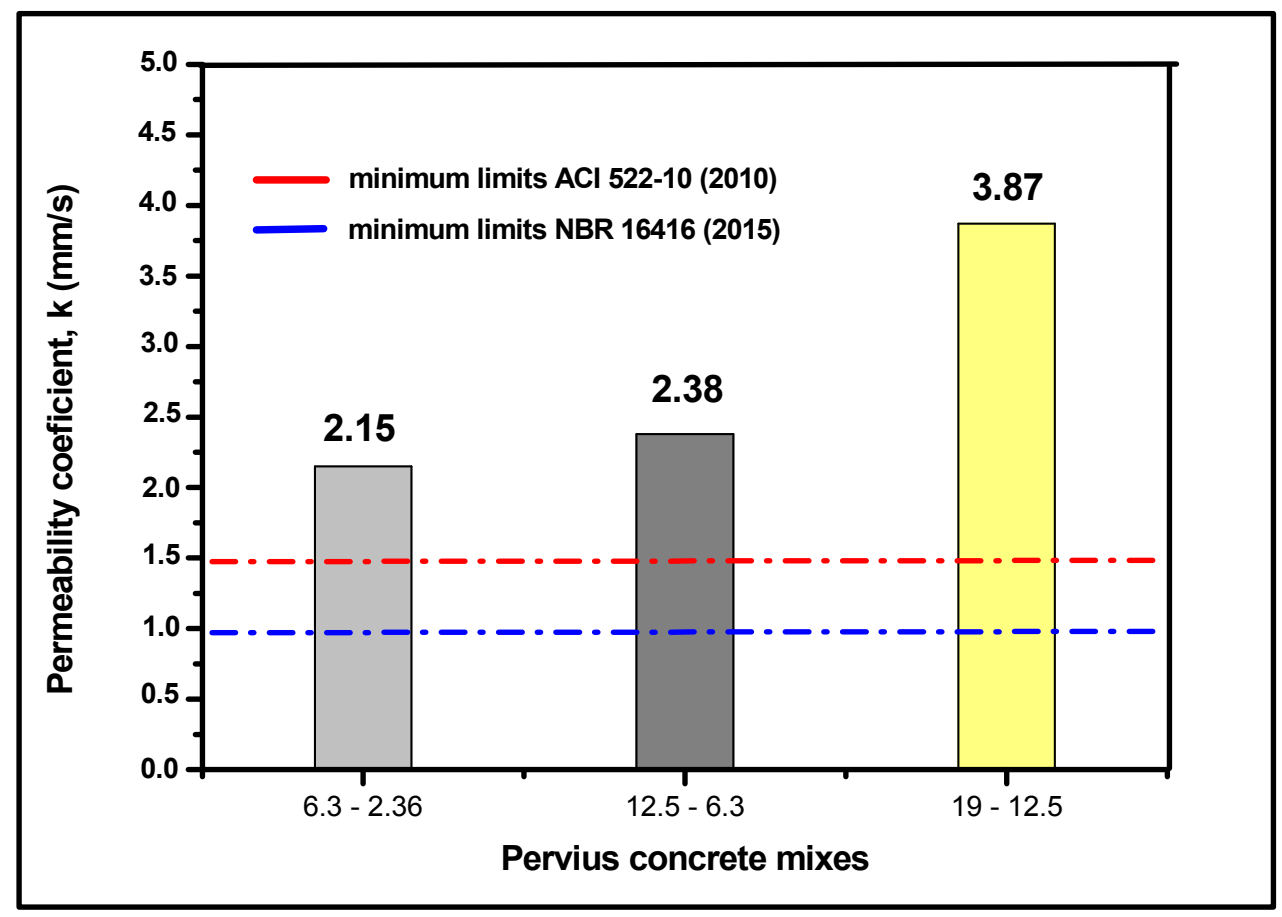

Fig. 8 Permeability coefficient $(k)$ of the porous concretes.

Fig. 9 shows the effect of particle size on the permeability coefficient for all evaluated pervious concretes. The strong relationship between the particle size and the permeability of the concrete, evidenced by the coefficient of determination of 0.85 , is clearly observed.

Fig. 10 shows that there was no correlation between the permeability and the total void index for the concrete produced in this research, demonstrating that the coefficient of permeability is not related to the total porosity of the concrete, but to the effective porosity. The interconnected pores are the ones that provided greater permeability to concretes.

The absence of correlation between the permeability coefficient and the total void index for the concretes studied is because not all pores are effective to allow water transport. There is an inactive porosity, which preferably occurs in pervious concretes with coarse aggregates of smaller size (4.75 $\mathrm{mm})$. These smaller pores have the greatest ability to trap water on the surface of their walls due to surface tension. For this reason, the permeability coefficient of the concrete mixtures tended to increase as the particle size increased, as seen in Fig. 9. The highest permeability coefficient of $3.87 \mathrm{~mm} / \mathrm{s}$ was achieved by mixing pervious concrete with particles of larger size between 12.5 and $19 \mathrm{~mm}$. The larger particles increase the concrete permeability because they do not fill the voids resulting from the removal of fine particles. This practice is also interesting because it slows pore clogging, which can reduce pavement maintenance costs.

\subsection{Flexural Tensile Strength}

The results of flexural strength are shown in Table 6. The dispersion of the results was high, with a standard deviation ranging from 0.37 to $0.85 \mathrm{MPa}$ and coefficients of variation between 14 and $22 \%$. This high dispersion of mechanical strength results is attributed to the high porosity inherent to the pervious concrete. The flexural strengths of the pervious concretes varied between 2.76 and $3.80 \mathrm{MPa}$ (mean 


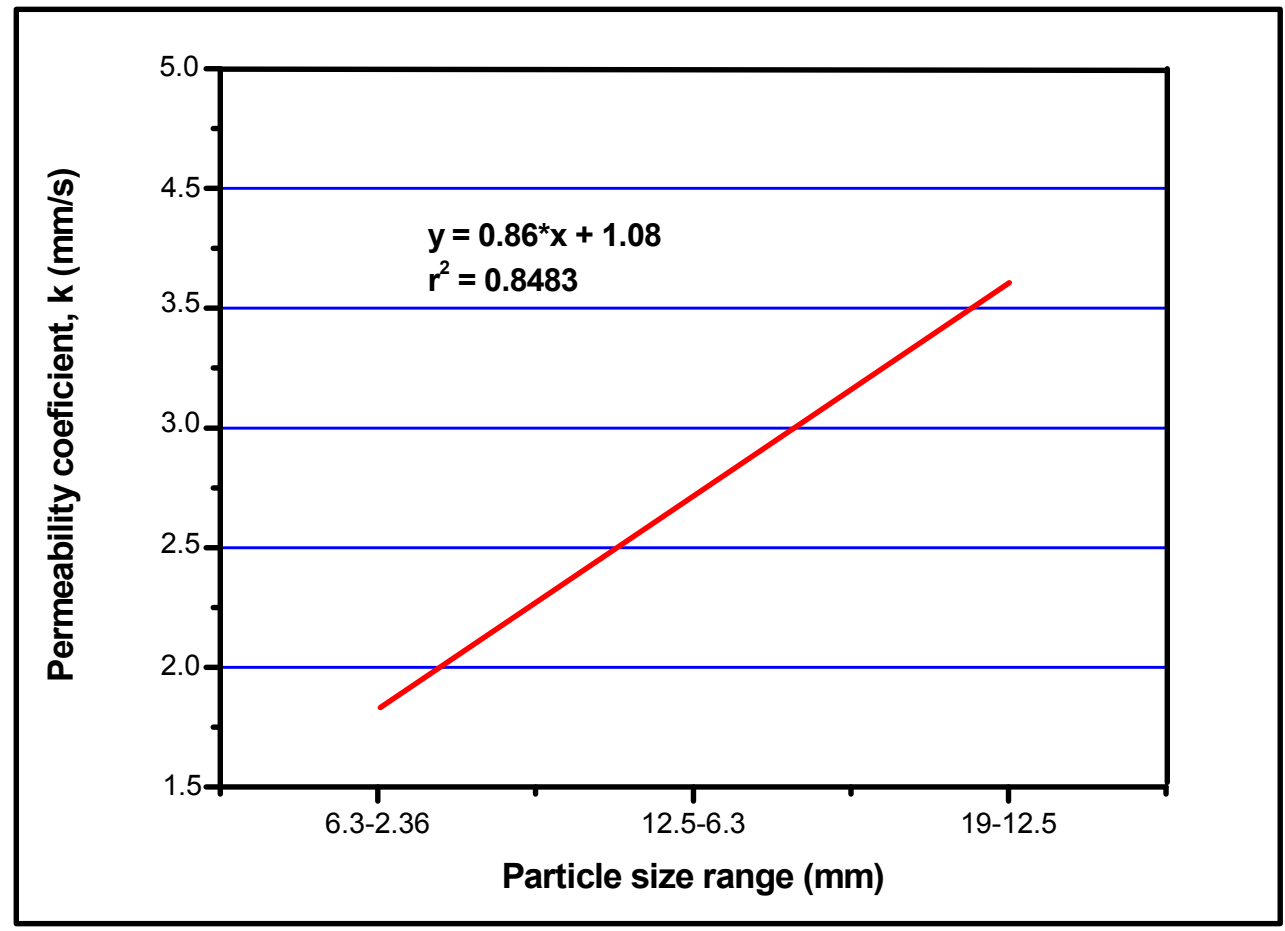

Fig. 9 Relation between permeability and particle size range.

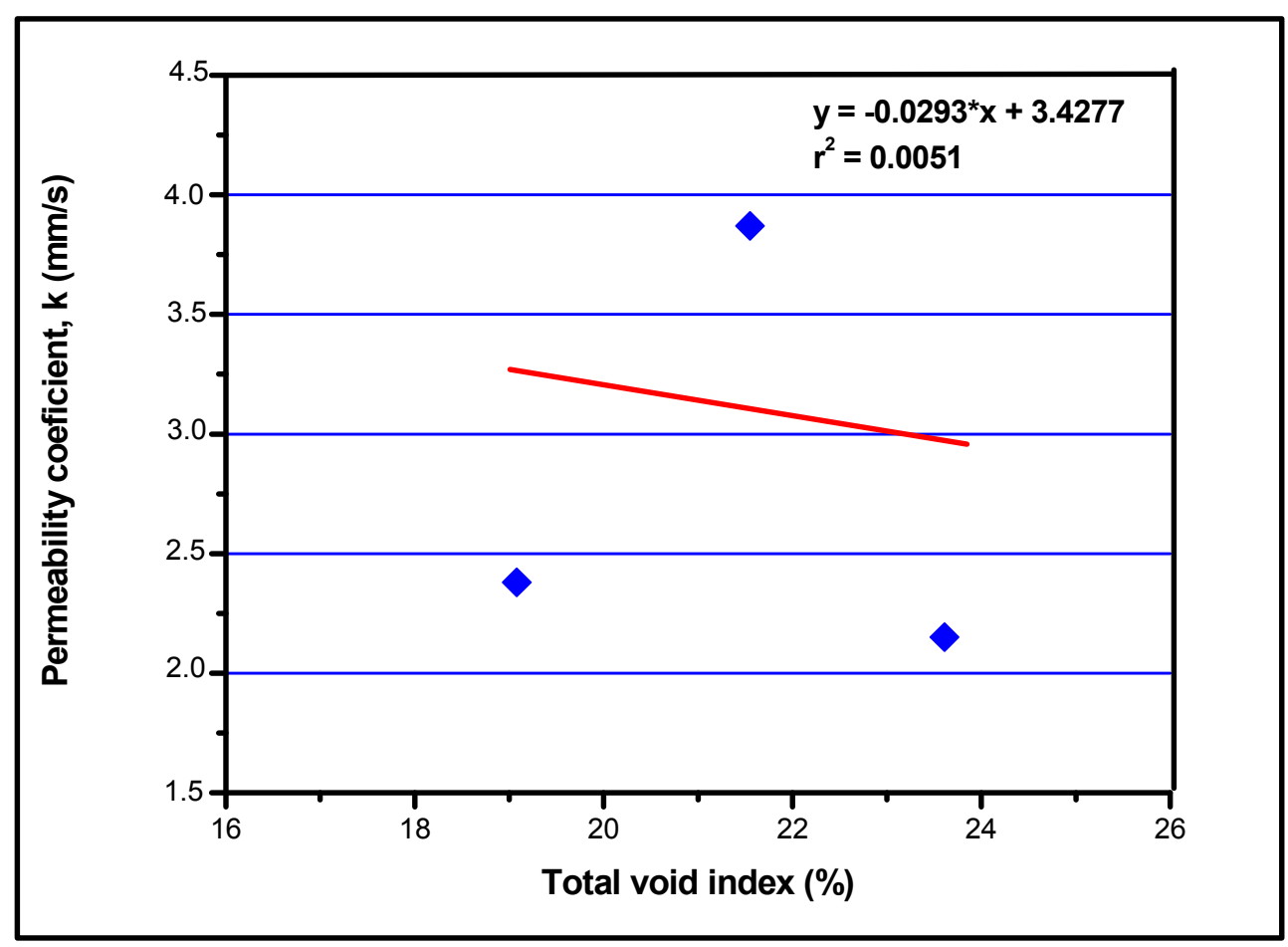

Fig. 10 Relation between permeability coefficient and total void index. 
Table 6 Flexural tensile strength of hardened concrete.

\begin{tabular}{lll}
\hline Mixture & Granulometric range $(\mathrm{mm})$ & Flexural strength $(\mathrm{MPa})$ \\
\hline U1 & $19-12.5$ & $3.43 \pm 0.723(21.07 \%)$ \\
U2 & $12.5-6.3$ & $3.80 \pm 0.85(22.4 \%)$ \\
U3 & $6.3-2.36$ & $2.76 \pm 0.37(13.55 \%)$ \\
\hline
\end{tabular}

Coefficients of variation: values between parentheses.

values), which is higher than the minimum limits stipulated by Brazilian standard ABNT NBR 16416.

The obtained flexural strength values associated with the high permeability coefficients also allow these pervious concretes produced with crushed granitic stone to be used as a revetment of permeable pavements for vehicle light traffic, indicating the broader potential of application in urban drainage projects in the MRB of non-structural and comprehensive design. The pervious concrete produced with gravel, the minimum of $2.0 \mathrm{MPa}$ required by the Brazilian standard for vehicle light traffic was not reached [10].

Fig. 11 shows the dispersion of the results with maximum and minimum values of each concrete mixture. Even considering the high dispersion of results, the lowest individual flexural tensile strength value, $2.40 \mathrm{MPa}$, obtained for the $\mathrm{U} 3$ mixture, was higher than the minimum required for vehicle light traffic, which means that all pervious concrete mixtures studied in this paper meet in practice the specifications in ABNT NBR 16416 (ABNT, 2015). The highest individual value of 4.70 $\mathrm{MPa}$ achieved for the $\mathrm{U} 2$ mixture was within the range of 4.0 to $5.0 \mathrm{MPa}$, which is normally used in road projects in Brazil.

Despite the higher cost of crushed granitic rock compared to gravel, the results indicate to be possible to employ pervious concrete in public walks and in lower traffic ways, which extends the possibilities of applying the permeable pavement in the watersheds of the MRB as a measure mitigating the floods, increase the percentage of permeable area in these basins.

Fig. 12 shows the excellent correlation that occurred between the flexural strength and the total void index with a coefficient of determination of 0.95 , which is different from what was observed for the permeability (Fig. 10). The correlation establishes that increases in flexural strength occur as the total porosity of the pervious concretes is reduced, confirming that the flexural strength is associated with total porosity, while the permeability depends on the effective porosity of the interconnected pores.

The relationship between the flexural strength and the particle size observed in Fig. 13 indicates a slight tendency of flexural strength to increase as coarse aggregates with larger particles are used. However, this correlation is not very strong, expressed by the reduced coefficient of determination $\left(r^{2}\right)$ of 0.4 .

In the majority of the papers found in the literature, the increase of the pervious concrete strength is observed when using coarse aggregates of smaller maximum characteristic diameter [30-33]. This occurs because the compressive and flexural strengths of the pervious concrete also depend on the area of cement paste that surrounds the aggregate particle and its strength. One way to increase the strength of the pervious concrete would be to employ aggregates of smaller particle size, which would increase the number of aggregates per volume unit, the specific surface area, and the amount of contact points between the particle bonds by the paste and would reduce the porosity [28]. However, because the particularities of this crushed granitic stone and the dosage parameters adopted in this research had been already discussed in previous topics, the tendency was that the mixtures with larger aggregate sizes, such as $\mathrm{U} 1$ and U2, presented the greatest mechanical strengths.

Fig. 14 shows the relation between the flexural strength and the apparent density of the hardened pervious 


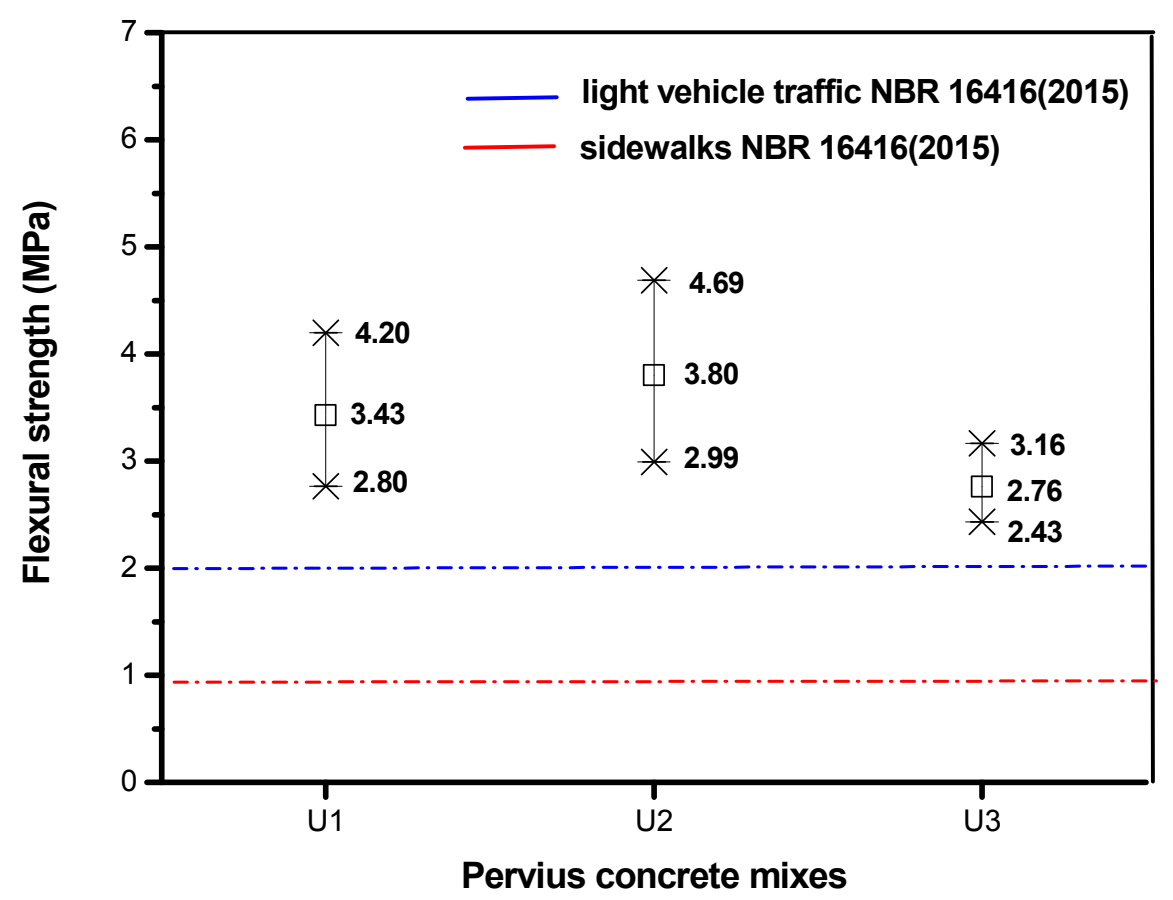

Fig. 11 Box plot of flexural strength.

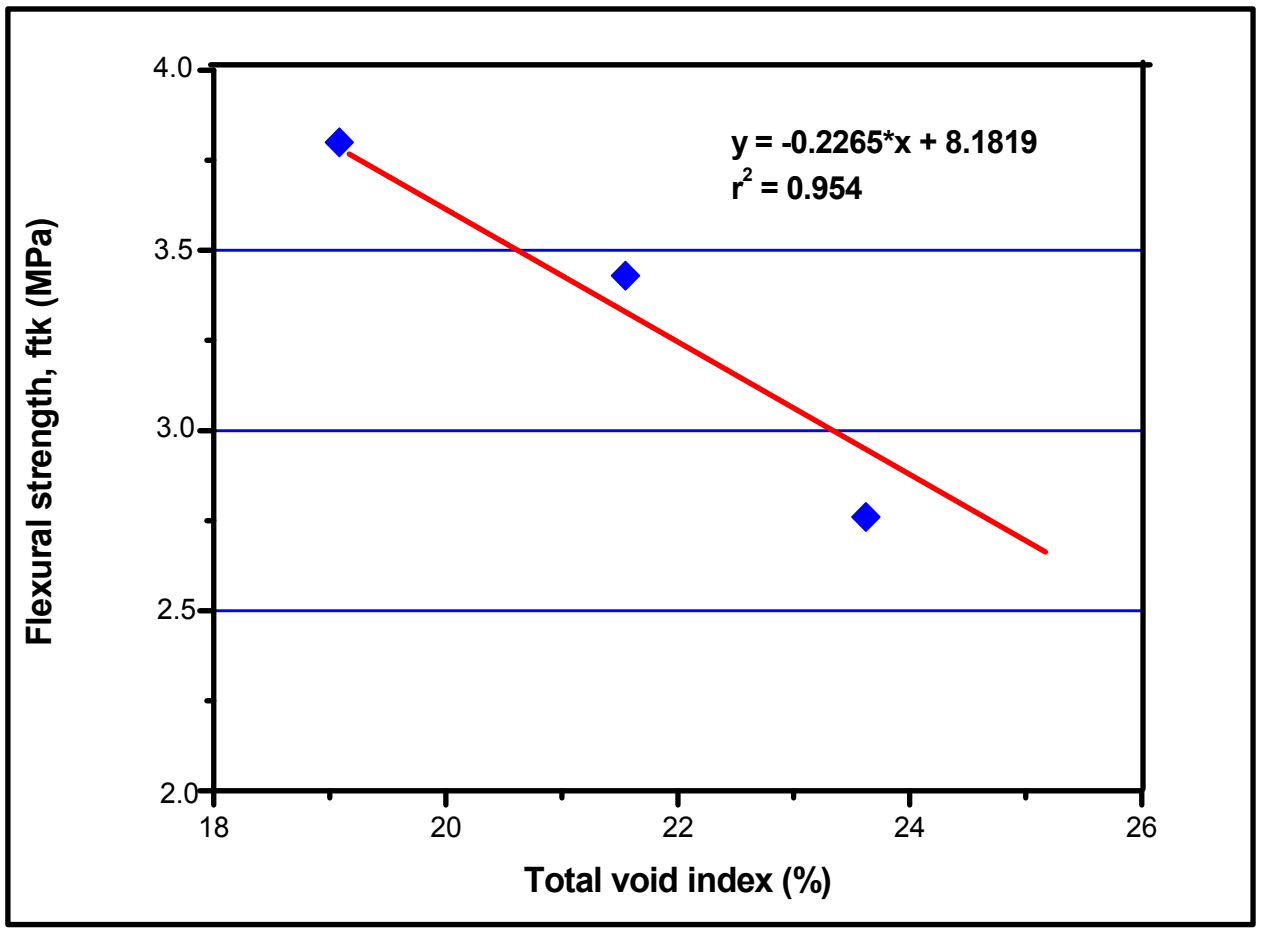

Fig. 12 Relation between flexural strength and total void index. 


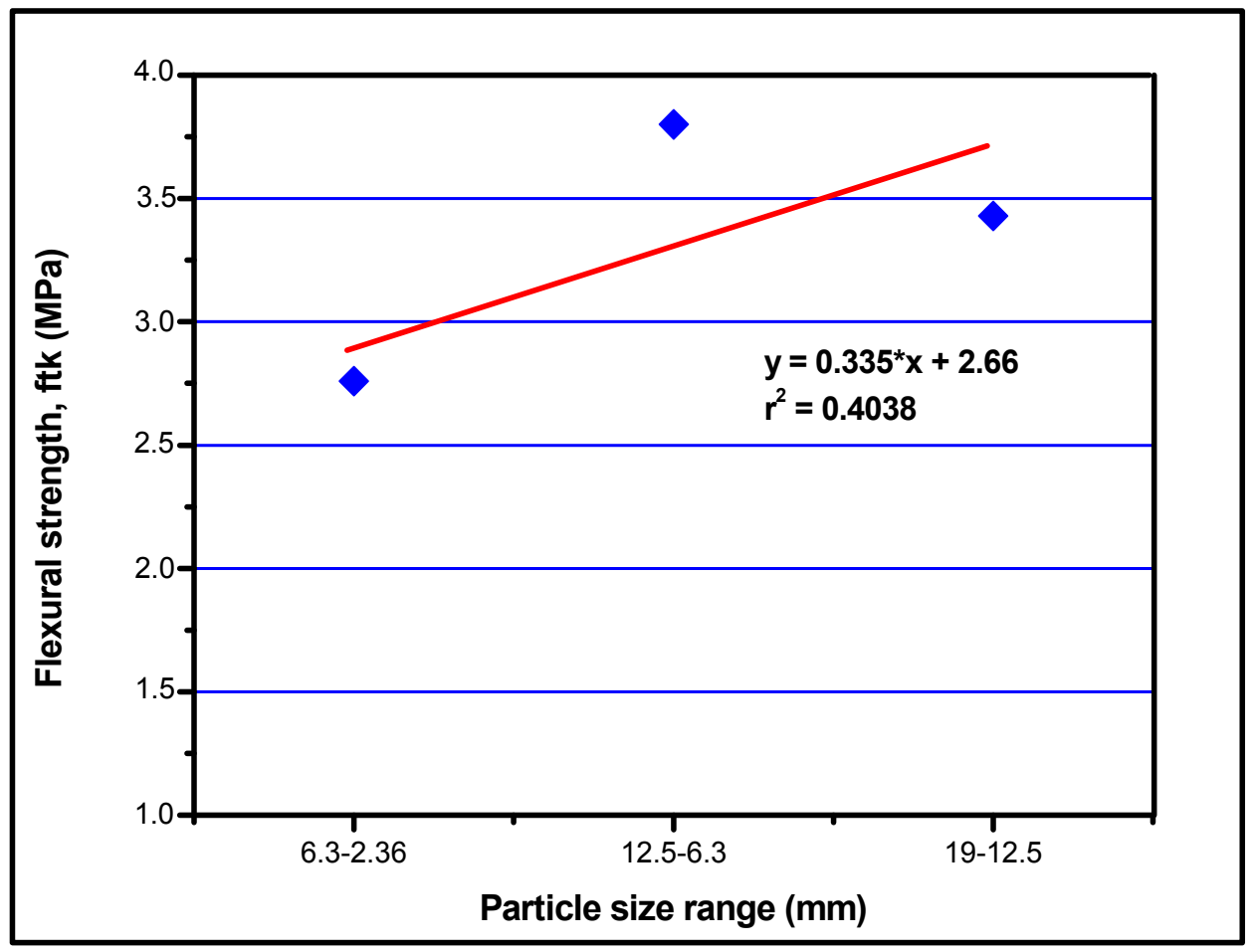

Fig. 13 Relation between flexural strength and particle size range.

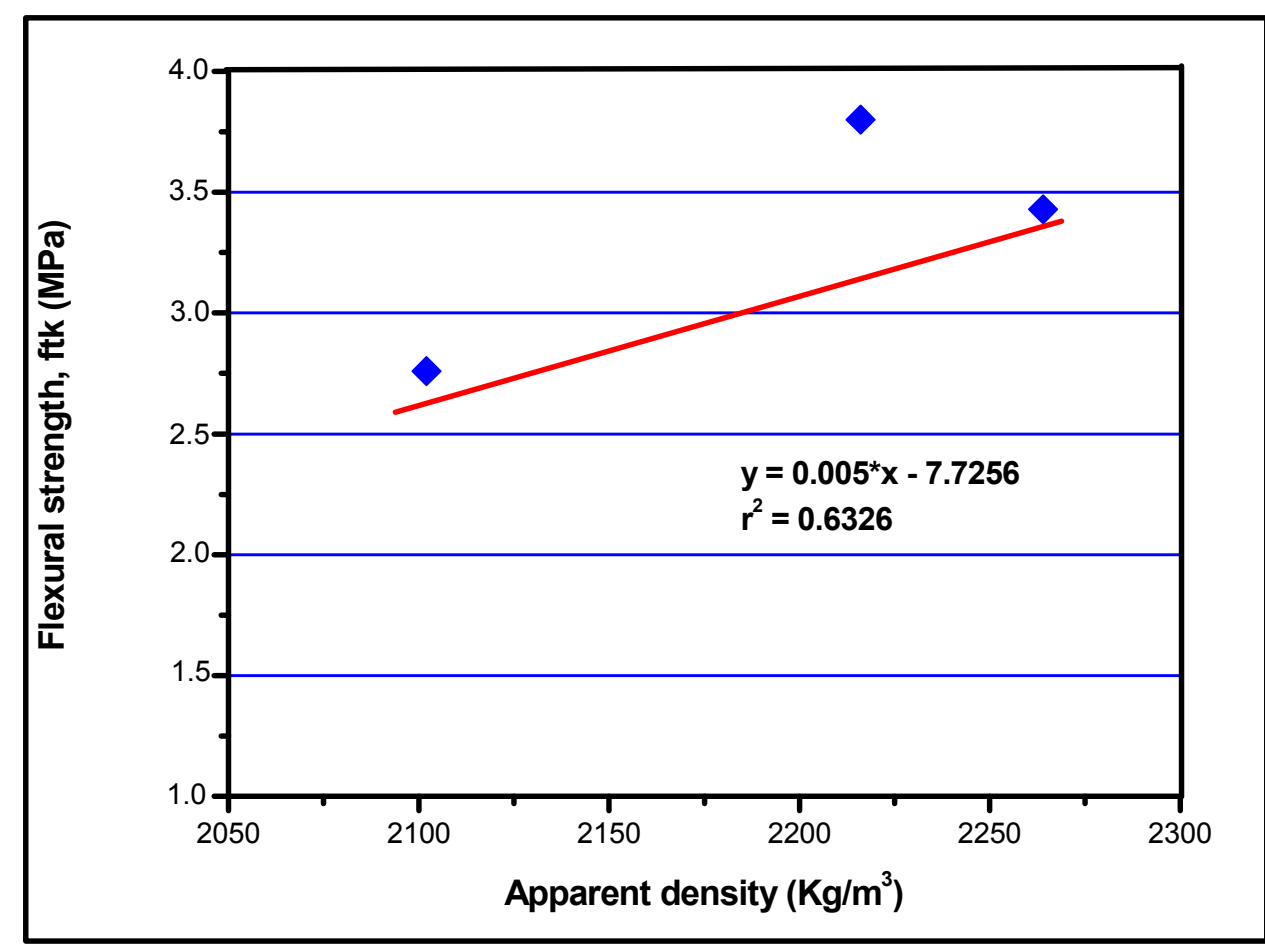

Fig. 14 Relation between flexural strength and apparent density. 
Table 7 Increase in the permeable area of the Una Basin.

\begin{tabular}{|c|c|c|c|c|}
\hline \multicolumn{3}{|c|}{ Sidewalk dimensions } & \multicolumn{2}{|l|}{ Permeable area } \\
\hline $\begin{array}{l}\text { Extension } \\
(\mathrm{km})\end{array}$ & $\begin{array}{l}\text { Wide } \\
(\mathrm{m})\end{array}$ & Area (ha) & Sidewalk/watershed ratio & Permeability after permeable pavement (\%) \\
\hline 466.0 & 3.0 & 139.8 & 3.88 & 22.54 \\
\hline
\end{tabular}

concrete. Similarly to the particle size, the flexural strength tended to increase as the apparent density of the pervious concrete increased. This correlation was representative and expressed by the coefficient of determination $\left(r^{2}\right)$ of 0.64 .

\subsection{Permeability of the Watershed}

The total replacement of the sidewalk pavement in normal concrete by permeable pavement technology represented approximately 140 ha, considering the total extension of the road system, in this case, 466 $\mathrm{km}$. This area would represent approximately $4 \%$ of the total area of its watershed, which is 3,607 ha. The permeable area would increase from the current $18.66 \%$ to approximately $23 \%$ (Table 7 ). According to the parameter of Schueler's diagram [16], the level of permeability of the Una Basin could be changed by incorporating permeable pavement in the extension of its road system, moving from a deficient situation to a range of acceptable values. Considering that this simulation takes into account minimum values, often below the existing sidewalk width in the urban occupation of the place, besides not considering the possibility of the use in secondary routes of less traffic, it is understood that the application in the real conditions can produce even greater gains in the permeability rate and thus objectively increase the urban-environmental performance of the urban basins and their occupation morphologies.

The total storage capacity of the permeable pavement system includes the capacity of the pervious concrete surface and the capacity of subbase used. The amount of water infiltrated in the subgrade was not considered because a permeable retention pavement was adopted. The permeable concrete surface with $15 \%$ of effective porosity and $100 \mathrm{~mm}$ of thickness holds up to $15 \mathrm{~mm}$ of rain before contributing to excess rainfall runoff. Compacted clean stone used as subbase, with design porosity of $40 \%$ and $150 \mathrm{~mm}$ thick layer, shows capability to hold up until $60 \mathrm{~mm}$ of rain. The total storage capacity of permeable pavement system would be $75 \mathrm{~mm}$ of rain. This value referred to sidewalk pavement is compatible with the normal rainfall regime that occurs in Belém (Table 1), and may mitigate flooding even for events outside of normal, as occurred in February 2018, with a rainfall index of $80 \mathrm{~mm}$. A critical assumption in this calculation is that the entire system is level, fact that is compatible with the flat relief of Belém.

Like all infrastructures, landscaping and urban drainage solutions called comprehensive or non-structural, such devices must be associated, working together, representing complementarity between classical structural solutions and comprehensive innovations capable of producing performance improvement [16].

\section{Conclusions}

From the results based on the laboratory tests and the simplified simulation of the permeable area of the watershed, the following can be concluded.

The apparent densities of the pervious concrete mixtures evaluated were high, all higher than 2,000 $\mathrm{kg} / \mathrm{m}^{3}$. The adoption of coarse aggregate/cement ratios less than 4 and the compaction procedure of the mixtures were the aspects responsible for this behavior, which had a favorable repercussion on the mechanical properties of these mixtures.

The permeability coefficients of the pervious concretes varied between 2.15 and $3.87 \mathrm{~mm} / \mathrm{s}$, and the flexural strengths varied between 2.76 and $3.80 \mathrm{MPa}$. Both parameters were much higher than the minimum limits stipulated by the Brazilian and American standards, enabling them as a revetment material for 
permeable pavements in both pedestrian and vehicle light traffic.

The permeability and flexural strength results showed that the water percolation rate is closely associated with the interconnected pores of the concrete mixture and not the total porosity (total void index), whereas the flexural strength strongly depends on the total porosity of concretes.

The use of mixtures with larger coarse aggregates provided the highest rates of water percolation without detriment to the flexural strength. The dosage criterion was responsible for this behavior. The establishment of a fixed percentage of cement paste volume provided a greater paste thickness to the mixtures with larger coarse aggregates, which had repercussions in the increase of the apparent density and flexural strength.

The results demonstrated that studies on the dosage of pervious concrete with emphasis on the control of cement paste thickness and the improvement of its strength could simultaneously provide high permeability and satisfactory mechanical properties, expanding the field of application of the pervious concrete mixtures.

Despite the higher cost of crushed granitic stone compared to gravel, the results showed that the use of this type of igneous rock provided the production of pervious concretes with high mechanical strength and satisfactory permeability.

The simplified simulation demonstrated that the permeable pavement technology could contribute to the improvement of the watershed drainage system. Only by replacing the public walkway pavement was there an increase of $4 \%$ in the permeable area of the watershed from 19 to $23 \%$. Of course, this contribution could be even more expressive, taking into account more realistic aspects, with a more precise survey of the walkway sizes and the possibility of including the use of permeable pavement in parking areas and secondary roads of the watersheds.
The total storage capacity of the permeable pavement for $100 \mathrm{~mm}$ tick of pervious concrete and $150 \mathrm{~mm}$ tick of compressed stone subbase was $75 \mathrm{~mm}$ of rainfall, compatible with the vast majority of the rains that occur in Belém. In addition, the fact of the city has flat relief allows the successful implementation of this technology. In this sense, permeable pavement has great potential for flood mitigation by being able to be designed for specific project rain.

In summary, the results indicate to be possible to employ pervious concrete not only in public sidewalks but mainly in pavements of light traffic, which extends the possibilities of applying the permeable pavement in the watersheds of the MRB as a measure mitigating the floods, increasing the percentage of permeable area in these basins as well as the storage capacity of rainfall. Thus, its more comprehensive use in watersheds associated with other comprehensive and structural measures would constitute a concrete possibility of improving the performance of the MRB drainage systems.

\section{Acknowledgements}

The authors thank the Pró-Reitoria de Pesquisa e Pós-Graduação (PROPESP) of Universidade Federal do Pará (UFPA) for their financial support through the Programa de Apoio à Publicação Qualificação, PAPQ (Qualified Publication Support Program).

\section{References}

[1] Virgiliis, A. L. C. 2009. "Procedimento de Projeto e Execução de Pavimentos permeáveis visando retenção e amortecimento de picos de cheia." M.Sc. thesis, Escola Politécnica, Universidade de São Paulo. http://www.teses. usp.br/teses/disponiveis/3/3138/tde-08092010-122549/ptbr.php.

[2] Castro, A. S. 2011. "Uso de Pavimentos Permeáveis e Coberturas Verdes no Controle Quali-Quantitativo do Escoamento Superficial Urbano." Ph.D. thesis, Universidade Federal do Rio Grande do Sul. http://hdl.handle.net/10183/55975.

[3] Pinto, L. L. C. A. 2011. "O Desempenho de Pavimentos Permeáveis como Medida Metigadora da 
Impemeabilização do Solo Urbano.” Ph.D. thesis, Escola Politécnica, Universidade de São Paulo. http://www.teses.usp.br/teses/disponiveis/3/3147/tde-310 82011-160233/pt-br.php.

[4] Ponte, J. P. X., Leão, M. B. M. S., Barros, N. S., and Cutrim, R. S. 2014. "Urbanização e Drenagem: Concepções Divergentes na Bacia da Estrada Nova." Presented at $3^{\circ}$ Seminário Nacional sobre o Tratamento de Áreas Preservação Permanente em Meio Urbano e Restrições Ambientais ao Parcelamento do Solo. http://anpur.org.br/app-urbana-2014/anais/ARQUIVOS/G T4-254-119-20140531021826.pdf.

[5] Martins, V. C. D. 2015. "Avaliação de sistemas de prevenção e contenção de inundações em bacia de drenagem urbana." M.Sc. thesis, Universidade Federal do Pará. http://ppgec.propesp.ufpa.br/ARQUIVOS/dissertac oes/2015/vania.pdf.

[6] Tucci, C. E. 2012. Gestão da drenagem Urbana. Technical report. Cepal. Escritório no Brasil/IPEA, Distrito Federal, Brasilia. https://repositorio.cepal.org/ bitstream/handle/11362/38004/1/LCBRSR274_pt.pdf.

[7] Bastos, T. X., Pacheco, N. A., Nechet, D., Sá, T. D. A. 2002. Aspectos climáticos de Belém nos últimos cem anos. Technical report for EMBRAPA, Belém, PA.

[8] Brandão, A. J. D. d. N., and Ponte, J. 2014. "Diretrizes urbanísticas para um plano de drenagem da Região Metropolitana de Belém." Presented at $3^{\circ}$ Seminário Nacional sobre o Tratamento de Áreas de Preservação Permanente em Meio Urbano e Restrições Ambientais ao Parcelamento do Solo. http://anpur.org.br/app-urbana -2014/anais/ARQUIVOS/GT4--98-20140804150556.pdf.

[9] G1. 2018. "Volume de chuva atinge marca histórica em Belém.” Accessed August 24, 2018. https://g1.globo.com/pa/para/noticia/volume-de-chuva-ati nge-marca-historica-em-belem.ghtml.

[10] Souza, R. S., and Carvalho, R. F. 2016. Concreto Poroso de seixo rolado para pavimentos permeáveis moldado no local. Technical report, Faculdade de Engenharia Civil, Universidade Federal do Pará. Belém, PA.

[11] Barata, M. S. 1998. "Concreto de alto desempenho no Pará: Estudo da viabilidade técnica e econômica de produção de concreto de alto desempenho com os materiais disponíveis em Belém através do emprego de adições de sílica ativa e metacaulim." M.Sc. thesis, Programa de Pós Graduação em Engenharia Civil, Universidade Federal do Rio Grande do Sul.

[12] Castro, J., Videla, C., Solminihac, H., and Fernandez, B. 2009. "Laboratory Study of Mixture Proportioning for Pervious Concrete Pavement." Revista Ingeniería de Construcción 24 (3): 271-84.

[13] Neithalath, N., Weiss, J., and Olek, J. 2006. Predicting the Permeability of Pervious Concrete (Enhanced
Porosity Concrete) from Non-destructive Electrical Measurements. Technical report for Clarkson University, Department of Civil and Environmental Engineering, Purdue University.

[14] COSANPA, GPHS-UFPA. 2008. Plano diretor do Sistema de esgotamento sanitário da Região Metropolitana de Belém. Technical report (org. José Almir Rodrigues Pereira) for COSANPA, Belém, PA.

[15] IDESP. 2012. Ruas da Região Metropolitana de Belém (Cartografia Digital, Format Shapefile by Thiago Allan Guedes Sabino and Andréa Lopes Pinheiro). Technical report for Instituto de Desenvolvimento Econômico, Social e Ambiental do Estado do Pará, Núcleo de Estudos Urbanos, Belém, PA.

[16] Araujo, G. H. S., Almeida, J. R. D., and Guerra, A. J. T., 2008. Gestão ambiental de áreas degradadas. Rio de Janeiro: Bertrand Brasil Press.

[17] Mascaró, J. L. 2003. Loteamentos Urbanos. Porto Alegre: +4 Press.

[18] Belém, Prefeitura Municipal de. 1999. Lei complementar de controle urbanístico. Lei complementar $n$. $^{\circ}$ 02, de 19 de julho de 1999. Dispõe sobre o parcelamento, ocupação e uso do solo urbano do Município de Belém e dá outras providências. $82 f$. Belém, Prefeitura Municipal. http://www.belem.pa.gov.br/segep/download/coletanea/P DF/n_urban_p/lccu.pdf.

[19] Tennis, P. D., Leming, M. L., and Akers, D. J. 2004. Pervious Concrete Pavements. Technical report for Portland Cement Association, Skokie, Illinois, and National Ready Mixed Concrete Association, Silver Spring, Maryland, USA.

[20] Batezini, R. 2013. "Preliminary Study on Pervious Concrete as the Surface Layer for Light Traffic Areas." M.Sc. thesis, Escola Politécnica, Universidade de São Paulo.

http://www.teses.usp.br/teses/disponiveis/3/3138/tde-190 72013-155819/en.php.

[21] Batezini, R., Curvo, F., and Balbo, J. T. 2016. "Estudo sobre o Comportamento Hidráulico de Concretos Permeáveis em Laboratório e Campo." Presented at Anais do XXX Congresso da ANPTE, Rio de Janeiro.

[22] Bonicelli, A., Giustozzi, F., and Crispino, M. 2015. "Experimental Study on the Effects of Fine Sand Addition on Differentially Compacted Pervious Concrete." Construction and Building Materials 91: 102-10.

[23] Brake, N. A., Allahdadi, H., and Adam, F. 2016. "Flexural Strength and Fracture Size Effects of Pervious Concrete." Construction and Building Materials 113: 536-43.

[24] Lian, C., and Zhuge, Y. 2010. "Optimum Mix Design of Enhanced Permeable Concrete-An Experimental 
Investigation." Construction and Building Materials 24 (12): 2664-71.

[25] Lian, C., Zhuge, Y., and Beecham, S. 2011. "The Relationship between Porosity and Strength for Porous Concrete." Construction and Building Materials 25 (11): 4294-8.

[26] Yang, J., and Jiang, G. 2003. "Experimental Study on Properties of Pervious Concrete Pavement Materials." Cement and Concrete Research 33 (3): 381-6.

[27] Shaefer, V., et al. 2006. Mix Design Development for Pervious Concrete in Cold Weather Climates. Technical report, Center for Transportation Research and Education, Iowa State University. http://www.ctre.iastate.edu/ reports/mix_design_pervious.pdf.

[28] Neville, A. M. 1997. Properties of Concrete. Edimburg: Person Press.

[29] Torres, A., Hu, J., and Ramos, A. 2015. "The Effect of the Cementitious Paste Thickness on the Performance of Pervious Concrete." Construction and Building Materials 95: 850-9.

[30] Meininger, R. C. 1988. "No-Fines Pervious Concrete for Paving." Concrete Internacional 10, Aug: 20-27.

[31] Nelson, P. M., Tsuruda, K., and Mirza, J. 1994. Designing Porous Road Surface to Reduce Traffic Noise. Technical report for Transportation Research Laboratory Annual Review, TRI, Crow Thorne, England.

[32] Bhuta, M. A., Tsuruda, K., and Mirza, J. 2012. "Evaluation of High-Performance Porous Concrete Properties." Journal Construction and Building Materials 31: 67-73.

[33] Huang, B., Wu, H., Shu, X., and Burdette, E. G. 2010. "Laboratory Evaluation of Permeability and Strength of Polymer-Modified Pervious Concrete." Construction and Building Materials 24 (5): 818-23. 